\title{
Democratization, Social Renegotiations and the Hegemony of the Rey Bouba Lamidate over the Population of Slavish Mboum Origin in Question in the District of Touboro (North Cameroon)
}

\author{
Assana \\ Researcher, Senior Lecturer \\ Department of Political Science, University of Ngaoundere \\ Cameroon \\ Email:assana_a@yahoo.fr
}

\begin{abstract}
This article analyzes the effects of democratization on power relations between the Rey-Bouba lamidate and the population of slavish Mboum origin in the district of Touboro (North Cameroon). The analysis of the challenges of its political participation (conventional and unconventional) leads to the study of its political activism in a context of diversification of the partisan offer. It also involves entering the profiles of political elites, from their rank and their associative movement. Based on the theory of coloniality of power and collected empirical data, democratization seems to be a favorable framework for social renegotiations between the lamidate of Rey-bouba and the population of the slavish Mboum origin.
\end{abstract}

Keywords---- democratization, multiparty system, political participation, social renegotiations, Rey Bouba lamidate, Touboro district (North Cameroon)

\section{INTRODUCTION}

The impact of democratization on traditional chiefdoms has been the subject of many debates and controversies. It was mainly considered under three (3) different analytical approaches. The first apprehends democratization as a mechanism which consecrates the enhancement of the position of traditional chiefdoms; the ability of traditional leaders to adapt to the various forces of change since colonization constitutes the cornerstone of this school of thought (On these questions, read, Ouedrago Jean Baptiste, 1996, pp. 249-261; Nyamjoh and Rowlands, 1998, pp. 320-337; Oomen Barbara, 2002; Perrot Claude-Helene et al, 2003; Ahmadou, 2019). The second analyzes democratization as a factor that contributes to the weakening of traditional chiefdoms (see among others Miaffo, 1993; Mouiche, 2001, pp. 55-81; Mouiche, 2005, pp. 221-249; Motaze Akam, 2009; Claude Abe, 2006, pp.). The third studies the ambivalent effects of democratization both on traditional chiefdoms and on slaves (Mouiche, 2005: pp221-249; Laservoisier, 2008: 247-267).

However, these first two approaches have a common setback, that of offering a partial reading grid of the ongoing political changes, induced in the lamidates by democratization: the first sins by political conservatism, that is, by minimizing the impact of democratization on traditional chiefdoms; the second seems to neglect the conservative adaptability of traditional chiefdoms. These analysis are therefore often carried out on the basis of questionable theoretical grids. In this way, the thesis of the ambivalence of the local effects of democratization seems more fruitful in this study. Indeed, the analysis of the impacts of democratization on the power relations between the population of slavish Mboum origin and the Rey-bouba lamidate must be guarded against two pitfalls.

The first, well known to social science when it comes to tackling sensitive subjects (Passeron, 1991), is the illusion of wretchedness which tends to describe "slaves" only as simple passive victims to be defended. This drift is particularly present in the speeches of human rights NGOs that tirelessly denounce "the enslavement of human beings". The second pitfall, also well known in our discipline, is that of "populism" which, unlike wretchedness, focuses excessively on the ability of slaves to resist domination. This approach amounts to making any person of bonded status a protestor, giving the society a conflicting image than it is actually is. It also tends to overestimate the autonomy of subordinate groups, thus neglecting the constraints and contradictions in which the subjects are caught (Laservoisier, 2008: p.2).

The aim of this article is to study the ambivalence of the trajectory of the negotiation of the emancipation of the ethnic group of the slavish Mboum origin of the Touboro district (North Cameroon) from the tutelage of the lamidate of Rey- Bouba in the democratic context. 
The issue of oppression in the Rey-bouba lamidate cannot be grasped out of colonialism. But, in general, this expansionist movement is expressed in two main forms: the external and the internal forms. External colonialism involves the balance of power between metropolises and indigenous populations, while internal colonialism establishes power relations between indigenous and non-indigenous populations ${ }^{1}$. Indeed, the arrival of the Fulani conquerors in the movement of jihad of Usman Dan Fodio at the beginning of the 19th century, led to the establishment of chiefdoms or Muslim lamidates and to the extension of the trans-Saharan slave networks towards the south, up to the Adamawa plateau (Ahmadou, 2019). Thus, the Rey Bouba lamidate that we propose to study constitutes a vast territorial and political unit organized around a centralized power under the control of a lamido. This lamidate extends to more than 35,000 km2 and includes more than 6,000 inhabitants"- (Mohammadou, 1966, p.266 cited by Abe, 2006, p.209-210) ${ }^{2}$. Similar to that of a real State, its political structure is based on three fundamental elements: The Head of State, the government and the decentralized bodies (Fogui, 1990, p.141). This Muslim chiefdom is undoubtedly the most powerful in northern Cameroon today. Most of his subjects are made up of ethnic groups: mboum, laka, mbere, Moundang, ngambaye etc.

The uniqueness of this lamidate lies in the political behavior of its lamido, especially at the time of the strategic alliances which preceded the independence of Cameroon. Its foundation is dated in 1798, at the end of the great Fulani conquest of Mali. Founded by the Yillaga fulani at the beginning of the 19th century, the kingdom of Rey covered the upper valley of the Bénoué. From the start, the Fulani element, which is very much in the minority, made this lamidate to project more like the extension of a the Dama principality, the main indigenous population, to the point where the Mboum of the Touboro area continue to call the lamido of Rey "Mbay Dama" meaning, the leader of the Dama (Seignobos, 2006: p.3). Rey marks his independence very early towards to Yola, the capital of Adamawa province, itself under the control of Sokkoto $^{3}$. As a reward for the help that Bouba Jama'a (1901-1945), Rey's third lamido, had given to the Brisset column during the 1914-1916 campaign which aimed to drive the Germans from Garoua, Rey was granted a special status. A promise was made according to which, until the death of his lamido, Rey would report directly to the High Commissioner of the French Republic, through the Head of the district of Garoua and that no administrative post would be established in within his area of command; which would be recalled by the decrees of 5-7-1993 and 24-12-1934 (Seignobos, 2006: p.3). In 1936, a subdivision of Bouba Ndjida was created without a "Chief town with fixed residence"4.

It is relevant to point out the fact that, the local hegemony of the Rey Bouba lamidate over the Kirdi ${ }^{5}$ was strengthened under the regime of President Ahmadou Ahidjo (1960/1982), who belonged to the Fulani ethnic group. The latter had opted, despite the constitutional principle of the respect for cultural differences and secularism, to erect the vast province $^{6}$ of northern Cameroon ${ }^{7}$ into a united and homogeneous Muslim bloc in terms of ethnicity, religion and administration (Mbembe, 1993, pp. 345-374 cited by Assana, 2017). The challenge was to constitute a regional power bloc in the response to the South with multiple divisions and to strengthen Islamic-Fulani domination ${ }^{8}$. It was in this context that the change of the head of State took place in 1982, where Paul Biya, a Christian from the South replaced Ahidjo. He will not break this heritage. In 1983, the new maneuver of Paul Biya, who became Head of State, consisted in resuming

\footnotetext{
${ }^{1}$ In this perspective, Motaze Akam makes a distinction between the "colonialisms of North Cameroon, understood as Fulani colonialism of Arab-Berber influence and European colonialism (German and French), in the liberal policy of the Cameroonian government" (1996: 83) cited by Assana, 2017.

${ }^{2}$ Population figures are estimates made in the 1960s, and today those numbers have likely tripled.

${ }^{3}$ Yola led several coalitions to end the Rey step, but to no avail. Rey presented himself at the end of the 19th century as the most powerful lamidate in Adamaoua and his relationship with Yola was nothing like that of vassal to overlord (Seignobos, 2006: p.3).

${ }^{4}$ The Garoua sub-divisional chief had to do a tour there. In all, there were twelve administrative rounds from 1918 to 1935. The death of Bouba Jama'a should have released the French administration from its "commitments", but for fear of offending the new lamido, Bouba Ahmadou (1945-1973), the installation of the Tcholliré post was put on hold, until the 1950s (Seignobos, 2006: p.3).

${ }^{5}$ Kirdi is an Arab-choa language term from Ouadai and Baguirmi meaning "unfaithful", that is, non-Muslim. It is used by the Fulanis (Kaado or Habé) to designate the non-islamic ethnic groups of North Cameroon. But this old name is no longer accurate as many Kirdi have converted to Islam and Christianity. The Kirdi are divided into three main groups: the mountain Kirdi of the mountainous area of Mandara, farmers; the Kirdi of the plain, farmers and pastoralists and the Kirdi residents of Logone, farmers, breeders and fishermen (Mouiche, 2000: 84; Bigombe, 1999: 240-241 cited by Assana, 2017). ${ }^{6}$ Provincial terminology was changed to region in 2008.

${ }^{7}$ There is no shortage of examples of the reorganization of administrative units in 1981, the former Head of State, Ahmadou Ahidjo had surprisingly demoted the Tchollire sub-division to the rank of district to insert it administratively within the district's command radius. of Rey-Bouba, held firmly by the lamido of the time, Moustapha Abdoulaye (see L'œil du Sahel $\mathrm{N}^{\circ} 443$ of August 16, 2011, p.2).

${ }^{8}$ The North / South clivage designates: "the attitude of the North which, in the mid-1950s, called for a radical split between Islamized North Cameroon and led by powerful chiefs called laamibé and Southern Cameroon where the influence of Christianity and Western civilization have penetrated more in the people "(Taguem Fah, 1996).
} 
the friendship from his predecessor for the lamido". From then on, Rey Bouba's lamido has positioned himself as the "black box", as the catalyst for the aspirations of local populations. In systemic language, he is the peripheral "gate keeper" of the demands and support of his people (Easton, 1974).

However, the democratization and liberalization that have energized the local political field since the 1990s seems to have a profound effect on the political behavior of ethnic groups formerly subservient to the Rey Bouba lamidate. In this context, the department of Mayo-Rey has seen the birth and development of attempts to emancipate the enslaved and dominated local population. The Mboum from the Touboro subdivision did not remain on the sidelines of these struggles for emancipation. This explains why we are witnessing more and more of ethnic irridentisms and the desire for empowerment in this district. This study addresses the problem of the place of traditional chiefdoms in this new context of democratization and political liberalization. Such a diagnosis requires that we first agree on the understanding of the entity being studied.

The concept of democratization is should be understood here, as a "negotiated process and not as a technical device" (Leservoisier, 2009, pp.24-43). This definition will allow us to go beyond an institutional approach (elections) here, by supplementing it with a study of the (unconventional) modalities of social renegotiations of power relations between the Rey-Bouba lamidate and the population of slavish Mboum origin in progress in the Touboro sub-division.

Regarding the concept of hegemony, it derives from the Greek word hegemon, which initially meant a commander-in-chief. It also signifies the supremacy of one political unit over all others (Nay, 2011, p.254). Hegemony refers to total domination, that is, domination without sharing. In the context of this study, hegemony implies a relation of total domination of the Rey-Bouba lamidate over the local populations. This domination is due to various reasons: to the historical conditions of colonialism; to the tensions between the order of indigenous governance (egalitarian societies / hierarchical and centralized societies); to the weight of the strategic alliances with the colonists which preceded independence (between the lamidate of Rey and the colonists); to the resilience of the forms of imposed governance through the concentration of most of the political, economic and socio-cultural resources in this division by the lamido of ReyBouba.

Can we perceive democratization as a mechanism which enshrines the liberation of the community of the slavish Mboum origin of the Touboro subdivision from the supervision of the Rey Bouba lamidate? To answer this question, we shall formulate a hypothesis according to which, democratization plays an important role in the social renegotiations ef for the emancipation of the Mboum population from the tutelage of the lamidate of Rey Bouba, by consecrating the passage from the culture of subjection to the culture participation ${ }^{10}$.

From a theoretical point of view, this study is based on the theory of the coloniality of power (Grosfoguel Ramón, 2004 , pp. 315-306). This theory is used to study the renegotiations of the liberation of the population of slavish Mboum origin from the tutelage of Rey Bouba's lamidate as recompositions of power relations of the colonial type, between dominant and dominated positions. Data was collected through documentary research, series of interviews (semi-structured and semi-participatory) conducted with five categories of actors: administrative authorities, political authorities, traditional authorities and ordinary citizens. The surveys were carried out from June 1 to 30, 2020 in the cities of Touboro, Mbaimboum and Mbang-Rey. The choice of these cities is motivated by the demographic concentration of Mboum and by their high rate of electoral participation. The discussion of the data collected gave rise to two types of concerns. The first presents democratization as a space for renegotiating the political balance of power between the lamidate of Rey and the Mboum community (I). The second articulation apprehends democratization as a space for renegotiating the socio-cultural balance of power between the lamidate of Rey and the Mboum (II) community in the Touboro sub-division.

\footnotetext{
${ }^{9}$ By lifting the subdivision of Rey-Bouba into a division that year, President Paul Biya designated against all expectation the town of Tcholire at that time the district head quarter, as the capital of the new division of Rey-Bouba instead of the town of Rey-Bouba itself which was the administrative capital of the division. Today we know that this choice responded to the desires of His Highness Moustapha Abdoulaye who did not wish to be disturbed by the representatives of the State. In 1984, the former divisional officer of Mayo-Rey Dawai Rou, was sacked after the violence that had as intention to uninstall the $2^{\text {nd }}$ class chiefs that were from the family of the lamido of Toboro, Tchollire and of Gamba. These chiefdoms have still not been provided with traditional chiefs from then (L'œeil du Sahel $\mathrm{N}^{\circ} 443$ du 16 août 2011, p.2).

${ }^{10}$ From the theoretical perspective of Gabriel Almond and Sydney Verba (1963 cited by Assana, 2019), the establishment of democratic culture leads to changes in political culture in the political field. It consecrates the passage of parish political culture, linked to traditional structures; the political culture of subjection, linked to centralized or authoritarian structures; to the political culture of participation, specific to democratic regimes. Alongside these categories, we must cite the acquisition of civic culture which constitutes for these authors, a fourth type: the cultural basis of democracy. This is a mixed type, which harmoniously combines the three, but with a participatory dominance.
} 


\section{DEMOCRATIZATION AS RENEGOTIATION OF POLITICAL BALANCE OF POWER BETWEEN THE REY-BOUBA LAMIDATE AND THE MBOUM IN THE TOUBORO DISTRICT}

Cameroon does not escape (or did not escape) the rule according to which only certain categories of the population participate in a more or less active way in political life, with the particularity that the regime of the first President Ahmadou Ahidjo was conservative with regard to State personnel. From this perspective, it is the "Islamo-Fulani bloc" that constitutes these complex socio-political actors which, in the postcolonial context of the first generation (1960-1982) appears as a leading category, especially in the North of Cameroon; but, within the Kirdi ethnic group, some members were co-opted into the politico-administrative hierarchy, alongside the Fulani, through Islamization. However, democratization has openly ask the question of the political participation of the original slavish Mboum group. To identify the issues of conventional participation on the dynamics of mboum emancipation, it is important to study the emergence of political personnel from this community (1) before analyzing the correlations between the explanatory variables (2).

\subsection{The emergence of mboum political staff}

To study the emergence of the political personnel of the slavish Mboum origin in the democratic movement, we will give more privilege to the municipal executive (1) more of a place of power, and for good reasons, studies have shown that in presidential regimes, it is the election to the presidency of the Republic, keystone of the institutions, which the voters rank at the top. Secondly, they place the municipal elections, to be the closest to their daily concerns, the municipality whose scale is reduced, allow them to easily perceive the link between their vote, public programs and the services actually obtained (see Mayer Nonna, Perrineau Pascal, 1992: 16 cited by Mouiche, 2011, p.22). Also, municipal elections mobilize many candidates capable of genuinely assessing the political weight and commitment of minorities, better than any other consultation (Fay 2000; Geshiere (Peter), 2006: 1-7; Mayer Nonna, Perrineau Pascal cited by Ibid.; to this, we put forward other complementary referents, particularly parliamentary representation (2).

\subsubsection{In the municipal executive}

The emergence of the Mboum political staff in local politics is a major political change in Touboro, where they have been providing political leadership in the council of this sub-division since 1993.

\begin{tabular}{|l|l|l|c|c|}
\hline $\begin{array}{l}\text { Names and } \\
\text { surnames of } \\
\text { Mayors }\end{array}$ & Mandate's duration & Ethnic group & Religious affiliation & $\begin{array}{l}\text { Political } \\
\text { affiliation }\end{array}$ \\
\hline Sebai Moussa & $1996 / 2013$ & Mboum & Muslim & NUDP \\
\hline Koulagna Nana & $2013 / 2017$ & Mboum & Muslim & NUDP \\
\hline Célestin Yindal & $2018-$ & Mboum & & NUDP \\
\hline
\end{tabular}

The council of Touboro was created by decree $n^{\circ} 1982 / 117$ of June 27, 1982 and has 196 villages. This municipality has almost 377,637 inhabitants. Historically, this council depended on Tchollire which is the capital of the Mayo-Rey division. The Mboum's control over the powers of the municipalities were carried out by the following Mayors: Sebai Moussa (1996/2013); Koulagna Nana (2013/2017) who died during his mandate and Célestin Yandal elected Mayor since 2018. The control of the municipal executive of the Touboro council by the mboum community can be explained by their hold on political support representation. This is manifested through the control of the leadership of the presidency of the NUDP Section of Ngaoui by Moussa Leounna (1992/2000). This section was created in 1992. Besides the municipal executive, the emergence of the Mboum political staff is also noticeable in the legislative functions.

\subsubsection{In legislative functions}

\begin{tabular}{|c|c|c|c|c|}
\hline $\begin{array}{l}\text { Names and } \\
\text { surnames of the } \\
\text { parliamentarians }\end{array}$ & Mandate's duration & Ethnic group & Religious affiliation & $\begin{array}{l}\text { Political } \\
\text { affiliation }\end{array}$ \\
\hline Sorobai ${ }^{\text {Joseph }}$ & $1987 / 1992$ & Mboum & christian & CPDM \\
\hline Koulagna Nana & 1992/1997 & Mboum & Muslim & NUDP \\
\hline $\begin{array}{l}\text { Kerbai Laoukoura } \\
\text { Jean Marie }\end{array}$ & $1997 / 2002$ & Mboum & christian & CPDM \\
\hline $\begin{array}{l}\text { Temhoul Lucie } \\
\text { Thomas }\end{array}$ & $2002 / 2007$ & Mboum & christian & CPDM \\
\hline
\end{tabular}




\begin{tabular}{|l|l|l|l|l|}
\hline $\begin{array}{l}\text { Kerbai Laoukoura } \\
\text { Jean Marie }\end{array}$ & $2007 / 2012$ & Mboum & christian & CPDM \\
\hline Abdel Azis Yaouba & $2012 / 2020$ & Mboum & Muslim, & CPDM \\
\hline
\end{tabular}

As we can see, the political leadership of the Mboum in the legislative functions corresponds to the context of relative relaxation of the single-party system that went from 1986 to 1990 . Indeed, the electoral consultations that took place then, that is the municipal elections of 1987 and legislative of 1988, were marked by the flexible single-party reference system whose mediators are the dominant. Indeed, these elections marked in the public political field, the competition between several lists invested by the single party (Sindjoun, 1999, p.279). These elections began the process of relative broadening of the structure of political choices. From then on, we ean observed the political leadership of the Mboum in legislative functions which is lasting: Joseph Sorobai (1987/1992), Christian Mboum; Koulagna Nana (1992/1997), Muslim Mboum; Jean Marie Kerbai Laoukoura (1997/2002), Christian Mboum; Temhoul Lucie Thomas (2002/2007); Jean Marie Kerbai Laoukoura (2007/2012), Christian Mboum; Abdel Azis Yaouba (2012/2020); Muslim Mboum. However, it is by studying the correlations between the multiple variables that we will analyze here the complex relations between democratization and the political renegotiations underway between the Mboum and the lamido of Rey in the Touboro sub-division.

\subsection{The correlation between the explanatory variables}

A certain number of variables linked to the structures of political opportunities make it possible to understand the emergence of political personnel of the slavish Mboum origin in the democratic movement: the diversification of the partisan offer and the ethnic vote (1) on the one hand, and the demographic framework and the profiles of elected officials (2) on the other hand.

\subsubsection{The diversification of the partisan offer and the ethnic vote}

Multiparty politics is an indicator of an open political market. The importance of power struggles within the framework of historic democratization in Africa can be seen at various levels: the emergence of political markets in most countries is characterized by multiparty politics, electoral competition or the systematization of elections (Bratton and Van de Walle, 1997). This multiplication of the partisan offer enshrines the extension of the right of entry of the population of the slavish Mboum origin into politics. In fact, the gateway from "elections without choice" with plebiscite results, to competitive elections with sometimes disputed transparency constitutes a paradigmatic break in the postcolonial political trajectory (Sindjoun, 1999, p. 271). It refers: "to the competition between several political actors and enterprises with a view to winning trophies such as the positions of municipal councilor, of parliamentarian and of the President of the Republic according to normative rules" (Sindjoun, 1999, p271). Under the decree of December 19, 1990 granting freedom to create political parties, several political parties were established in the Department of Mayo-Rey. However, two political parties are dominant in Touboro. The Cameroonian People Democratic Movement (CPDM), born from the dissolution of the defunct Cameroonian National Union (CNU), once a single party which was created at the Bamenda Congress held from March $21^{\text {st }}$ to $24^{\text {th }} 1985$; its ideology is community liberalism and, the President of the Republic of Cameroon, Mr. Paul Biya has been the President of this party since its birth. Besides the CPDM, the National Union for Democracy and Progress (NUDP) is another influential political party. The NUDP is one of the opposition political parties created in support of the restoration of multipartism in Cameroon ${ }^{11}$. It is headed by Bello Bouba Maigari, a Fulani prince from Bascheo (near Garoua) in the North region of Cameroon. He was accused of being nostalgic of the past and the standard bearer of the Islamo-Fulani group in North region of Cameroon (Ahmadou, 2019: 29). In this context, the struggles between political parties are opportunities for the emancipation for the Mboum community.

The observation of the double ballot (municipal and legislative) of 2018 in the Touboro district indeed revealed that, political parties are more and more forced to invest the members of the subordinate categories as head of the list and to grant them an important number of seats as municipal councilors, under the penalty of losing an important political clientele. According to field survey, the choice to place people of slavish Mboum origin on the eligible lists is part of the anticipation strategies that political parties engage in among themselves. These strategies show that the constitution of the eligible lists is a subject of intense negotiations during which the ethnic variable, without being exclusive, plays an important role ${ }^{12}$. Three extracts from interviews with people born in the fifties (50s), laid emphases on the importance of

\footnotetext{
${ }^{11}$ The UNDP was recognized as a legal political party on March 25, 1991 with its headquarters in the city of Yaoundé.

${ }^{12}$ In view of the electoral system in force in Cameroon, the more a candidate occupies a good position on the list, the more he has the chances of passing. If there is an absolute majority, the entire list is elected; if on the other hand it is the relative majority; half of the list is elected. Subsequently, in the application of the proportional system, some candidates may have the chance to be elected. These are precisely the candidates who immediately follow the last name of the first half previously elected (Read Kuate, 2002, p.38).
} 
the multiplication and diversification of the partisane offer in the current political renegotiations in Touboro sub-division. According to the first informant,

The multiplication and diversification of the partisan offer is an important tool of political renegotiations for the Mboum in Touboro. Indeed, the Mboum became aware of the fact that, by millitating within the CPDM, they would remain under the political tutelage of Rey Bouba's lamidate. Therefore, the political activism of the majority of the Mboum community in the opposition parties in this case the NUDP, participates in the logic of dissociating the lamido of Rey and its ally the central power. Indeed, the Mboum who are in search of political inclusion resorted to the political parties of the opposition, as a means to undermine the political party in power (CPDM) which is generally seen as the guarantor of the interests of Rey Bouba's lamidate. Politically, the lamido had become accustomed to appointing or investing people loyal to him. The highly educated young people are excluded and the municipal councilors are representative of the dogaris and the village heads committed to him. In reality, it is a means of controlling municipal revenue in the four councils of the Rey-Bouba department. In Touboro for example, the Additional Cummunal Centimes (ACD) donated by FEICOM to the municipality of Touboro is managed by the lamido, who takes care of its distribution. The parking of trucks leaving to and coming from Chad is managed by the lamido's men. However, this shift towards the opposition enshrines the politico-economic decline of the said lamido in Touboro; given that economically, Touboro and Madingring are the main centers of cotton, corn, agricultural peanuts, and pastoral cattle and sheep. There are also three cotton ginning factories in the Mayo Rey Division, including two in the subdivisions of Touboro and Tcholliré. Almost half of Cameroonian cotton comes from the Mayo-Rey Division. In 2003, the lamibe of the Far North received 15 FCFA in rebate per $\mathrm{kg}$ of cotton produced in their territory in order to fight against illegal export to neighboring States. It is the lamido's men that control the exit of food from the division and levy a tax of 500 FCFA per bag of maize, millet or peanuts leaving the division (Interview of 15/06/2020 in Touboro).

Based on the words of this informant, the conclusion that emerges is that political activism within the opposition parties appears to be an important modality of political renegotiation for the Mboum community. Through their electoral choice, some members of the Mboum community have used the NUDP as a strategic weapon aimed at weakening the political and economic hegemony of Rey Bouba's lamido. In other words, the thesis of the economic fragilisation of the Rey Bouba lamidate holds on the economic weight of the Touboro sub-division, given that this sub-division home to the city of Mbaiboum which has established itself as a hub of major trade between Nigeria and the countries of Central Africa within the Division of Rey Bouba (Read Karine Bennafla, 1998, pp. 54 and 67). In addition to its economic weight, this division is also striking for the size and density of its population. It covers an area of 85,000 square kilometers. It has almost 377,637 inhabitants (read the Touboro Communal Plan on these points, 2014, p.24). In addition, the Touboro subdivision is also a home to the most important municipality of this Division from the point of view of its administrative account $^{13}$, the number of its municipal councilors (41 municipal councilors against 21 for the municipalities of Ray, Tcholliré and Madinring) and, its public account in 2019 amounts to 1,000,000,000 320 million (one billion three hundred and twenty million). According to the testimony of the second informant:

The activism of the Mboum community in the opposition parties was concomitant with to the awareness of the new generation of Mboum in the year 2000. In fact, the Mboum from this generation believed that the time has come to free themselves from the yoke of the chief and manage the local resources of Touboro. This generation has taken the electoral weapon as its instrument. Unlike the older generation whose slavery left deep traces and stubborn prejudices in their minds, the new generation sees voter turnout as an important weapon that can lead to political emancipation. From then on, democratization appears in the eyes of this new generation as an important moment of recomposing power relations, and even settling the historical dispute which inevitably linked them to the lamido of Rey-Bouba since his foray into North Cameroon. This new generation increasingly digests living in political insignificance and cultural anonymity (Interview of $06 / 15 / 2020$ in Touboro).

\footnotetext{
${ }^{13}$ The administrative account of a council is a document drawn up and presented by the Mayor to the municipal council for approval. This includes all income and expenditure for each section (operation and investment) for the past year and certifies the correct application of the original budget and the amending budgets. In Cameroon, the administrative account is an important variable in the categorization of councils. According to Article 16 of the Decree No. 2020/528 of September 2, 2020 fixing the terms of remuneration, allowances and other benefits allocated to members of the executive and deliberative bodies of the Regions, Urban Councils and Municipalities, urban councils and municipalities are classified according to the budget volume: more than 5,000,000,000 ( $1^{\text {st }}$ class $)$; between 2,000,000,001 and 5,000,000,000 ( $2^{\text {nd }}$ class); between 5,000,000,001 and 2,000,000,000 ( $3^{\text {rd }}$ class ); less than 500,000,000 ( th $^{\text {class }}$ ). Based on this categorization, the council of Touboro is $2^{\text {nd }}$ class with regard to its administrative account which is above 1,000,000,000 FCFA.
} 
The purpose of the above makes it possible to apprehend the Mboum youth as an important factor in political renegotiations in the Touboro. The demographically and sociopolitically very important young Mboum generation finds itself at odds with the lamidal order most often. Indeed, in the social field of the fight for human rights, the young Mboum generation is active, and relaunches the debate on entirely new political bases. The arrival in 2005 of the mobile phone networks ${ }^{14}$, refused by lamido Bouba Abdoulaye until his death (Seignobos, 2006: p. 5), can only reinforce the thesis of the weakening of Rey-Bouba's hegemony. The thesis of the decline of the hegemony of the Rey-Bouba lamido is also based on decree ${ }^{\circ} 128$ of 04 July 2007 signed by the former Prime Minister Inoni Éphraïm and confirming the designation of Aboubakary Abdoulaye as of Head of $1^{\text {st }}$ class chief of Rey-Bouba and in particular of its 1 st article which provides that:

As of October 14, 2006, the designation made according to the regulatory procedure, of Mr. Aboubakary Abdoulaye, as $1^{\text {st }}$ class Chief of Rey-Bouba (71,873 inhabitants), district of Rey-Bouba, Department of Mayo-Rey, is approved as of October 14, 2006, Northern Province, replacing Mr. Moustapha Abdoulaye, deceased ${ }^{15}$.

In the view shared by a large number of informants, this decree was part of the central power's desire to subtly reduce the influence of Rey Bouba's lamido over the entire Mayo Rey division (36,000 $\mathrm{km} 2)$. This decree on the delimitation of the territorial competences of the Rey-Bouba lamidate only revived the mobilization of the new generation of mboum in favor of emancipation. However, this decree is more of a political maneuver intended to calm local protests than a concrete measure. Notable reservations were expressed by some of the respondents on the thesis of the decline of the political and economic hegemony of the lamido of Rey. According to the third informant:

The decline of lamido Rey-Bouba's hegemony in the Touboro sub-division should not be absolute because of its conservative adaptability or the channeling of democratic change. Admittedly, He lost his monopoly in the sub-division which is the economic heart of the division of Rey, but he preserved his politico-economic hegemony not only over part of the Mboum population but also over the other sub-divisions (councils): Madinring, Tcholliré and Rey-that remained under the influence of the CPDM. He is also a member of the Political Bureau of the CPDM, 1st Vice-President of the Senate, and the President of the regional and divisional commissions of the CPDM in the North region. He remains the privileged political intermediary between the central power and the Northern Region. He exploits his political potency within the CPDM to preserve his local hegemony. In fact, 70\% of the municipal councilors invested by the CPDM, as well as all the Mayors, the parliamentarians and the Senators who are elected in the division of Rey are acclaimed by the lamido of Rey Bouba. In these municipalities, the lamido of Rey continues to rule (Interview of $16 / 06 / 2020$ in Touboro).

The conquest of the council of Touboro can give the illusion of a profound change or (using systemic jargon) of a split in the political black box. However, things are more complex and require the political scientist to take a step back. In other words, the loss of the hold of Rey Bouba's lamido over the town of Touboro reflects not a total loss of the magisterium of influence of Rey Bouba's lamido, but a bipolarization of the local political field, characterized by the emergence of new dissident political actors. Starting from the words of this informant, we can legitimately observe that the local political field in the division of Rey Bouba is still dominated by the political paternalism of Rey Bouba's lamido. On this point, it is clear that the postures of allegiance of certain members of the Mboum community are still perpetuated today for strategic, cultural, psychological and even mythological reasons. According to Ahmadou Sehou:

Their ancestors would have predicted the arrival of a more powerful people whom they should not resist but rather with whom one should collaborate or else provoke the wrath of the gods. According to this tradition, the Mboum were to return to their city after the fall of the third rock at the top of the Ngaoundéré (literally, "the mountain in the navel"), which gave the city its name. At the top of this mountain were arranged three blocks of rocks; the first would have fallen at the time of the Fulani conquest, the second at the time of the German conquest; only the third is still visible today (Mohamadou, 1999: p.28 cited by Ahmadou, 2019: 22).

Certain testimonies also state the curses incurred by the victims of slavery who would deny their masters. Sometimes the access to legislative responsibilities of a person of the slavish Mboum origin can be a reward for political loyalty, the political rise of Senator Namyo Pierre of Mboum origin who is a secular arm of the Rey-Bouba lamido is an example. This categorical mobilization should not obscure the internal divisions within the slavish category. Political factionalism or the logics of ethno-clan fragmentation in the Mboum community benefit Rey Bouba's lamido.

\footnotetext{
${ }^{14}$ Young people as the actors of social change, read Niang, 2007, p.7-8.

${ }^{15}$ The decree obtained the visa of the President of the Republic before being initialed by a Prime Minister, himself a Traditional ruler. 07/02/2007. On this subject, read L’œil du Sahel N ${ }^{\circ} 443$ of August 16, 2011, p.2.
} 
However, it would be reductive to interpret the dynamics of the liberation of the population of the slavish Mboum origin through the sole grid of electoral participation. Here as elsewhere, explanatory monism must be avoided ${ }^{16}$ : Far from being in itself a sufficient condition for the political emergence of the descendants of Mboum slaves, the establishment of elections therefore turns out to be in reality a catalyst of multiple variable explanations of the dynamic emancipation already at work in Touboro. It is by crossing democratization with other variables such as the demographic backbone of the Mboum and the profiles of elected officials from their rank that we can better understand the complexity of the current dynamic emancipation of this people in the Touboro sub-division.

\subsubsection{The demographic backbone of the Mboum and the profiles of elected officials}

The emergence of the Mboum political staff in the Touboro is also due to the demographic backbone, profiles and personal trajectories of the elected officials. It is important to study the influence of the demographic backbone before that of the profile of local elected officials.

The demographic issue is at the heart of the current political renegotiations in the Touboro. Numerical data on the ethnic composition of the population of this sub-division, from its origins to present day, and on the demographic evolution of the Mboum migration to this locality are really lacking in the available literature. Demographic statistics are imprecise. Nevertheless, cross-checks of historical data make it possible to fill this gap. According to the work of Michèle Delneuf et al, the Mboum and the Dii constitute the majority ethnic groups in this sub-division (Michèle Delneuf et al, op.cit, p.14). The electoral weight is thus more and more often used as an argument and a means of pressure on political parties to figure prominently on the eligible lists. From the Durkheimian perspective, the general idea here is that a large population has a moral density and a sufficient electorate to play a subsequent political role. Likewise, the alibi of electoral competition led the opposition political parties like the NUDP to rely primarily on majority ethnic groups. Structural assimilation of political parties refers to the proportional distribution of ethnic groups in party structures and nominations ${ }^{17}$. Given the significant demographic growth, and hence, electoral growth of the Mboum, almost all parties quickly attracted candidates of Mboum origin to their lists. Looking at the profiles of municipal executives and Mboum parliamentarians, there is a tendency within political parties to consolidate an ethnic electoral niche. While the Cameroon People's Democratic Movement (CPDM) clearly has the greatest sociological diversity on the lists, the opposition party, the National Union for Democracy and Progress (NUDP) is trying to catch up, by focusing more on the mboum community. As Olivier Laservoisier observed in the haalpulaar society of Mauritania:

political elections are thus the object of power struggles and intense negotiations between social groups, suggesting that the democratic debate takes place less in pre-electoral discussions on the programs of political parties, than in the search for compromises and changes in alliances that agitate society during the polls (Laservoisier, 2008: 41).

This shows in passing that, ethnic affiliations to political parties are based less on their programs than on local issues and in particular on the nature of social relations. The examination of some personal trajectories of elected officials of the slavish Mboum origin shows that the political success also depends on other criteria, including that of their personal qualities. Putting the examples of Nana Koulagna and Célestin Yandal into perspective will allow us to better appreciate the challenges of recognizing mobility in the context of power relations.

To properly assess the impact of Nana Koulagna's profiles on the ongoing political renegotiations, it is important to briefly mention his political biography. He distinguished himself as an early political opponent in the Department of Mayo Rey. Born around 1946 in Ndindang in the Touboro sub-division, he is a descendant of Belaka Nya Mbaka, the great Chief Mbéré who reigned as Master in the current sub-division of Nyamabaka. Nana Koulagna was entrusted to the whites by his father so that he could attend modern school. It was in this sense that he was sent to Tcholliré, about $300 \mathrm{~km}$ from his village Ndindang, to do primary studies. A teacher and veterinarian by training, Nana Koulagna began to display his political ambitions under the reign of lamido Bouba Ahmadou. It was the acts of abuse of power by Rey Boub's lamido in the Rey Bouba division that prompted him to engage in politics (Interview of 06/17/2020 with Mbaim mboum). To do this, he presented his candidacy for the legislative elections in 1970. In 1972, he again stood for the federal legislative elections within the Cameroonian National Union (CNU), but he was again defeated by Abdoulaye Ahmadou for the post of Federal Parliamentarian and the seat of parliament of Eastern Cameroon was attributed to his brother-in-law, Moussa Maliki. Nevertheless, he won a seat of Municipal Councilor in the council of Tcholliré in 1987. This is the place to point out that the advent of multipartism in Cameroon has breathed new life into his political struggle under Nana Koulagna. He was an activist in the NUDP from the early hours to the point of becoming an influential member. After the 1992 elections, the NUDP won all the seats of MP. Not happy to override the ban on residence in Rey Bouba's territory, this parliamentarian publicly demanded the liberation of the populations of Mayo Rey from the grip of lamido (KW, 2002, p.56 cited by Ibid,

\footnotetext{
${ }^{16}$ The analysis of traditional political societies has long suffered from the stubbornness of explanatory monism (for useful reading and linear evolutionism (Joya, 1996, p. 1).

${ }^{17}$ On the importance of the demographic variable; see Mouiche, 2011, p.22; Mouiche, 2012.
} 
p216). After several years of political endurance, he was rewarded in 1992, the year of the first multiparty elections as a Member of Parliament. After a few years of imprisonment, he reappeared on the political scene in 2002. It remains that the conflict which opposed him to the lamido of Rey reveals all the difficulty for a person from a subordinate category to have their success fully recognized when this is translated into the crossing of social borders. Following the elections of September 30, 2013, he was also elected Mayor of the Touboro council. In the case of Nana Koulagna, his relative level of education and his socio-professional status constituted a source of social distinction. Nana Koulagna's social success and his actions in favor of others enabled him to establish his local reputation. His example also illustrates how socioprofessional success can be used for political ends, either to help challenge a traditional chief or to become a local elected official. These different distinctions, which transcend statutory affiliations, blur the old dividing lines between traditional social categories. They also lead to the questioning of the perceptions that members of the Mboum community have of Nana Koulagna's mobility and the meaning they give to his political struggle:

In the collective representation in the Mayo Rey Division, Nana Koulagna embodies the figure of the liberation of the population of the slavish Mboum origin from the tutelage of the lamidal order of Rey Bouba; the symbol of the fight for freedom, equality, social justice and human rights. In the 90s, the Belaka (the traditional Mboum chiefs) understood the importance of coalescing with people whose social distinction offer the best guarantee in the perpetuation of the fight for the liberation of the population of the slavish Mboum origin, through the defense of their interests, protection of land rights. At the end of the consultation between the traditional Mboum chiefs, an ally had to be found to continue the fight for the liberation of the Mboum population, hence the focus on Koulagna Nana. This cause had to be carried by an influential Mboum personality. This is why the traditional leaders found it useful to come to terms with Koulagna. They found Koulagna Nana, a professional veterinarian in the town of Bertoua in the East region of Cameroon. It was more precisely the Belaka Aliou Nana who co-opted Koulagna Nana. With the election of Koulagna in 2013 as the Mayor of Touboro, the Mboum seized this platform to denounce the abuse of the Lamido of Rey-Bouba and by questioning the Human Rights Commission (Interview of 06/17/2020 to Mbaim Mboum).

In addition to Nana Koulagna, the example of Célestin Yandal, current Mayor of the council of Touboro since 2018 also show that the political success of local elected officials is largely linked to their personal trajectories. It is representative of these new figures of socio-political success. Born in 1982, he decided in the mid-1990s to get involved politically in his town of Touboro, after having studied law at the Faculty of Law and Political Science of the University of Ngaoundéré (Cameroon). Very early on, his social courage, his sense of organization, his political ambition and his connections with Nana Koulagna led him to assert himself as the leader and the undisputed defender of human rights in the Touboro sub-division. A human rights activist, his political notoriety was built on the denunciation of the abuses and atrocities of the Rey-Bouba lamido on the local populations of the Mayo-Rey Division. With a master's degree in Public Law, his level of education is a source of social distinction, given that it offers the best guarantee to defend the interests of the local population. He was thus the President of the collective of Touboro youths created in 1991, which served as a springboard for his political career. Regularly struggling with Rey Bouba's lamido, he served in Tcholliré prison in 2013. Célestin Yandal's political era therefore took a considerable proportion both in the sub-division of Touboro and in division of Mayo-Rey. In just a few years, he has become the undisputed figurehead in the fight against slavery and the conquest of the rights of local populations. Célestin Yandal's militant career and his popularity pushed him to run for municipal elections. It was in 2017 that he achieved his first real political success by being elected City Councilor and especially $1^{\text {st }}$ Deputy Mayor of the council of Touboro (2013/2017) to Mayor Nana Koulagna. It was following the death of the main Mayor Koulagna Nana, that he assumed the interim (2017/2018), before being elected main Mayor in 2018. According to an informant:

Like Nana Koulagna, Célestin Yandal was committed to defending the interests of his group by participating particularly in the creation of the collective which brought together young people. The purpose of this association was to raise awareness among young people by organizing activities or denouncing the various forms of discrimination to which local populations could be subjected to. Célestin Yandal's commitment thus reveals the importance of an intergenerational transmission of a political struggle for liberation. The ideological heritage transmitted by Nana Koulagna shows that the dynamics of emancipation were already at work within the Mboum community. It was this desire for emancipation that led Célestin Yandal to opt for the Faculty of Law at the University of Ngaoundéré. Célestin Yandal's political rise can also be explained by his human rights activism and political courage. From then on, he gained the political sympathy of his community. But his political rise is also due to his personal qualities, his political courage and his ability to seize the opportunities offered by his educationt. In fact, on certain walls, in the city and even in the villages of the sub-division, messages are displayed magnifying the change that has taken place. Like this message read by the roadside in Tapi (a village located about thirty kilometers from Touboro): "NUDP liberator, freedom in Mayo-Rey"! Well done Yandal! But he is also an elected official concerned with the development of Touboro. He recently made a visit to the United States in June 2008, in order to find foreign partners and carry out development actions in the fields of education and health. There is no doubt that this episode will 
have a positive impact on the political notoriety of Célestin Yandal ${ }^{18}$. These actions have enabled him to gain the esteem of before the local population and a certain notoriety, which has led him to be approached by village officials to become politically involved. Thus, the election of this man comes above all from the skills acquired in the associative movement (Interview of 06/08/2020 in Touboro).

Based on the foregoing elements, the local elected representative must be understood as a "plural actor", that is, someone who has participated successively during his personal trajectories or simultaneously during the same period of time in various social universes by occupying different positions. In other words, the local elected official is endowed with several potentials from which he will display in a given situation, depending on his objectives, his strategies and the networks in which he operates, and an identity, even a composite identity game (Read on this question, Lahire, p.19; Constant Martin, 1992, p.42). As we can see, access to elected positions is therefore not based only on electoral participation alone, but in reality, on the combination of several variables. However, the political progress of the community of the slavish Mboum origin cannot be fully appreciated without taking into account socio-cultural renegotiations.

\section{DEMOCRATIZATION AS RENEGOTIATIONS OF THE SOCIO-CULTURAL BALANCE OF POWER BETWEEN THE MBOUM OF THE TOUBORO DISTRICT AND THE REY-BOUBA LAMIDATE}

The affirmation and protection of cultural diversity through the consecration of freedom of association in the 1990s is an important modality of socio-cultural renegotiations in Touboro. Several associations defending identity interests have emerged. The example of the Mboum Cultural Dynamics is emblematic on this point. It deserves more attention as, on reflecting on the reorganizations on the fringes of the electoral process, it reveals the full political significance of this association. The Mboum Cultural Dynamics (MCD) aims to be:

the crucible of meeting and communion of the Mboum sons and daughters, in order to strengthen the bonds
of solidarity and fraternity, to promote a better knowledge of their history and to promote the economic,
social, cultural and intellectual development of a Mboum man (see the status of Cultural Dynamics Mboum).

It was born during the Unitary Congress which was held from August $13^{\text {th }}$ to $15^{\text {th }}, 2004$, which brought together the Mang-Ndéré, Mang-Mbéré and Mang-Mboum clans ${ }^{19}$. On analysis, this association has seen the emergence of two main missions: cultural promotion (A) on one hand, socio-economic development and the trivialization of public anger (B) on the other hand.

\subsection{Cultural promotion}

According to Tove and Michelle Gazzola, cultural capital refers to symbols, ideas, tastes and preferences that can strategically be used as resources in collective actions. Culture ensures cohesion between members of the same community and strengthens feelings of solidarity and belonging to a specific group (Rocher, 1992: 110-116). The Mboum Cultural Dynamics as a framework for cultural promotion, contributes to the reconstruction of the Mboum collective identity (1) on one hand, and the demands for the reclassification of Mboum traditional chiefdoms (2) on the other hand.

\subsubsection{The reconstruction of the mboum collective identity}

The Mboum community is increasingly seeking to control its cultural destiny, because culture is recognized as a fundamental reality which commands all real development (World Report on Human Development, 2004: 28). It participates in the formation of collective identity. The Mboum Cultural Dynamics (MCD) aims to develop the village, the sub-division and the tribal area. The most emblematic case is the Mgbor-yanga. This is the biggest mboum cultural meeting which took place from April 10 to 12. For 3 days, the Mboum sons and daughters revisit their rich cultural heritage. The theme of the 913th edition of the Mgbor-yanga festival of the Mboum people (the horse trail) was: "Culture, peace and social cohesion". This meeting mobilized more than 700 Mboum sons and daughters, coming from various horizons. A highly enriched program of activities through traditional dances such as the "Ndja" (the main Mboum dance), the warrior parade, the fashion show, fairs and exhibitions of art objects, wood sculptures, pottery, basketry, and many other objects. There were also stories, folk tales, theater... the Mboum heritage is represented by a horse track, symbol of Mgbor-yanga.

\footnotetext{
${ }^{18}$ As J. Schmitz and M.-E. Humery, with regard to the Podor department in Senegal, development activities offer real opportunities for promotion and recognition for the actors, particularly from subordinate groups, cited Laservoisier Olivier, 2008.

${ }^{19}$ The Mboum of this $21^{\text {st }}$ century have taken the resolution to unite their clan diversities to resume their place as indigenous people of the Cameroonian central plateau, of which their parents were dispossessed thanks to the coalition of Ardo Djobdi, Hamn Sambo and Bouba Djidda, all lamibes from Ngaoundere, Tibati and Rey-bouba during their crusade against the Mboum ». Read the Reply relating to the complaint against his Majesty the Belaka Mboum-pana ( $2^{\text {nd }}$ module by RB).
} 
At the end of the third day, the participants experience a return to their roots in the caves of Nganha, navel of the Mboum people (Alert $\mathrm{N}^{\circ} 039$ from April 28 to May 15, 2015: 5).

Since its creation in 2004, Mboum Cultural Dynamic (MCD) has launched a project to build a Mboum Cultural Center in Ngaoundéré. However, this project is still at the aspiration stage, as the acquisition of land remains problematic. In this cultural center, Mboum art objects will be exhibited and made available to the public, just like what happens in museums. This is the place to specify that the MCD in its operations maintain collaborative relations with other cultural associations. During the last general assembly, held from 07 to 09 April 2011 in Ngaoundéré, the members of sister associations like the Mouvement d'Intégration et d'Assistance Mutuelle (MOINAM) of the Gbaya, the ACD, the Bassa community -Mpo o-Bati of Ngaoundéré (COBAMB), the Bamougoum community of Ngaoundéré, the Association of Mambila Women (AFEMA) were invited. Collaboration strategies with other associations are materialized by the attempt to create the Gbaya-Dii-Mboum branch (Assana, 2017). This attempt to build the Gbaya-Dii-Mboum branch is based on historical links (Deoyo, 2013). This pooling of resources has severely affected the notables at the lamibé court of Adamaoua. According to Sehou Ahmadou:

The lamido of Ngaoundere lost many of its mboum and dourou servants who deserted the royal court under the effect of these associations (saoumboum, association of Mboum), Tag Daga (association of Dourou), MOINAM (association of Gbaya), just to name a few. For the latter, the lamidat and its leader, because of the "Foulbe matter" still continue to impose their hegemony over the Kirdi. The action of these associations was carried at the national level through campaigns cleverly orchestrated and most often carried out by the political or administrative elite, coming from these different groups, or from groups sharing the same reading in other parts of the country. By awakening certain poorly healed wounds, they sometimes lead to extreme tensions or deadly clashes (Ahmadou, 2019: p.9).

In addition to the reconstruction of collective identity, the MCD constitutes a platform for complaints about the reclassification of the Mboum chiefdoms.

\subsubsection{The claims of the reclassification of mboum chiefdoms}

The demand for the reclassification of chiefdoms by the subordinate Mboum group are undoubtedly one of the most obvious illustrations of the scope of the social renegotiations of the current socio-cultural balance of power in the Touboro sub-vision. One of the major objectives of the Mboum Cultural Dynamics (MCD) is the rehabilitation of traditional Mboum chiefdoms. According to field surveys, a range of factors is at the origin of the claims relating to the reclassification of the Mboum chiefdoms: the deliberate maintenance of the Mboum chiefdoms in the $3^{\text {rd }}$ class status, the confiscation of the acts of homologation of the so-called traditional chiefdoms by the lamido of Rey-Bouba and the subjugation of the traditional mboum chiefdoms to the lamidate of Rey-Bouba. The leaders of this association intended to reconstitute the traditional fabric of the Mboum. According to the president of Mboum Cultural Dynamics:,

The problem is real in the geographical area where the Mboums are located (...). All the higher Belaka.... are still the third-class leaders. Moreover, this is one of the essential struggles of the Mboum Cultural Dynamics, to ensure that the state revalorizes the classification of Mboum traditional chiefs. We don't have second class leaders let alone $1^{\text {st }}$ class. As a result, the Mboums are absent from many important meetings. For example, when the head of state comes to visit Ngaoundéré... they are not there. He does not meet the Mboum Chiefs on the pretext that they are third class chiefs. The first request we addressed to the Head of State is to enhance the status of our traditional leaders. It is a permanent battle (Alert No. 034 from April 28 to May 15, 2015: p8).

The political stakes of these demands are of several types: first, the reclassification is aimed at strengthening the traditional Mboum chiefdoms through their reclassification to $2^{\text {nd }}$ and $1^{\text {st }}$ class chiefs. Secondly, it aims at increasing the possibility for Mboum traditional chiefs to obtain an audience with the Head of State during regional tours ${ }^{20}$, and also to increase the possibility of eligibility for the electoral college of senators. It is to be understood that these demands arise in a political context where, decentralization contributes to the revalorization of traditional chiefdoms by taking into account chiefdoms in the competences transferred to them and their representation in the Senate and regional councils. The new constitution of Cameroon of 1996, within the framework of regional decentralization, opened a bridge for the representation of traditional authorities within regional councils. Under Article 57 sub-section 2, the regional council which is the deliberative organ of the Region, also includes, divisional delegates elected by indirect universal suffrage, and representatives of the traditional command elected by their peers. Likewise, they would necessarily have representation

${ }^{20}$ This is because in practice, only traditional chiefs of the $1^{\text {st }}$ and $2^{\text {nd }}$ class were entitled to hearings granted by the Head of State during so-called regional tours. 
within the Senate provided for by the constitution, among the three of the ten senators from the regions appointed by the Head of State (Read usefully Mouiche, 2005, p.24-25; Assana, 2014, p.29).

Finally, these claims were underpinned by financial issues. From now on, all the traditional chiefs will receive monthly, "a fixed allowance calculated on the basis of the numerical size of their population as well as an allowance for special charges" and the statue of their traditional chiefdom whose amount is fixed at 200000 FCFA for $1^{\text {st }}$ class chiefs, 100,000 FCFA for $2^{\text {nd }}$ class chiefs and 50,000 FCFA for $3^{\text {rd }}$ class chiefs ${ }^{21}$. Things that could exacerbate greed and explain the renewed interest in the demand for the reclassification of traditional Touboro chiefdoms to $2^{\text {nd }}$ class chief. Through this reclassification, their position will be further strengthened in traditional power. Such a demand testifies to the current political changes in particular the democratic effects on Mboum political imaginary and practices. In addition to the reconstruction of collective identity and the demand for the reclassification of Mboum chiefdoms, the Mboum Cultural Dynamics MCD) also pursues socio-economic development and the trivialization of public anger.

\subsection{Socio-economic development and the trivialization of public anger}

The higher the socio-economic status of a group, the greater the chance for it to be engage in politics ${ }^{22}$. This perspective has been the subject of several studies which identify a link between socio-economic status, the presence of associations within a group and its propensity to participate in political life within the society (Arcand, 2003: 20). The Mboum Cultural Dynamics (MCD) nurtures socio-economic ambitions in its objectives (1) and also participates in the trivialization of public anger (2).

\subsubsection{Socio-economic development}

The Mboum Cultural Dynamics (MCD) promotes the economic development of the Mboum people. To this end:

It seeks ways and means that can contribute to the development of the Mboum people;

$>$ It studies profitable projects and analyzes the conditions for their implementation;

$>$ It encourages community initiatives and the creation of Common Initiative Groups (CIGs);

$>$ She seeks the addresses of NGOs capable of supporting the effort of economic development and draws up the list for wide distribution to the Mboum community ${ }^{23}$.

Considering their low level of scholarization, the Mboum Cultural Dynamics (MCD) also promotes education. This requires the acquisition of knowledge, qualifications and certificates essential for any socio-professional integration. To achieve this, the Mboum political elites take charge of the best Mboum pupils and students each year. This bonus consists of the granting of school materials and / or a financial contribution for the payment of tuition fees ${ }^{24}$. A member of this association explains the merits of this operation in these terms:

Our commitment to the Mboum Cultural Dynamics (MDC) aims to promote massive and advanced schooling in the Mboum community. Historically, Rey's lamido is believed to have subtly planned the Mboum's deprivation of schooling. Indeed, the geographical location of the schools was not favorable to the Mboum. Starting from Touboro to Mbang Ray, there were only three (3) schools (Touboro, Hankao and Mbang Ray. A student who finished primary school in Mbang Ray for example, had to travel $500 \mathrm{~km}$ to access the class of form one in Hankao. However, with the election of Koulagna to the municipal executive of Touboro in 2013, the school map of the Touboro sub-vision has clearly improved. From then on, each village now has a school. Extremely selective, the lamido of Ray-Bouba took measures to limit the access of Mboum children to the general secondary cycle. training schools such as the National School of Administration and Magistracy (ENAM), the Institute of International Relations of Cameroon, the CUSS, the Higher Teachers' Training College (ENS) while his family attended the prestigious schools at the effect of ensuring the social reproduction. Touboro's educated Mboum elites had to leave the Rey Division or benefit from their parents' assignments in other areas. Today, our major challenge is to encourage the young generation to go as far as possible in acquiring knowledge, which will transform the Mboum community (Interview of 06/18/2020 in Mbang-Rey).

\footnotetext{
${ }^{21}$ See article 22 of Decree No. 2013/332 of September 13, 2013 amending and supplementing certain provisions of Decree No. $77 / 245$ of July 15, 1977, on the organization of traditional chiefdoms.

22 Socio-economic status can be defined as the educational and income levels of individuals. It explains the differential socio-political integration of ethnic minority structures, the political choices of individuals and gives meaning to their way of thinking, perceiving and acting (Gerber, 2006, p.67).

${ }^{23}$ See MDC Internal Rules.

${ }^{24}$ This commitment to education can be translated into achievements. For example, during Nana Koulagna's tenure as the Touboro municipal executive, he devoted 70,000,000 per year to promote education in the Mboum community.
} 
The above makes it possible to observe that, education is an important modality of renegotiation for the liberation of the Mboum community from the tutelage of the Rey Bouba lamidate. It is the open door to independence and access to full citizenship. Indeed, the quality of human resources of an ethnic group in terms of education is an important variable in the dynamics of political recruitment. As Luc Sindjoun attests, "the enrollment and literacy rate is also an indicator of educational power. It reveals the proportion of the population capable of assimilating and possibly producing knowledge, ideas ..." (Sindjoun, 2007, p.22). Furthermore, informants agree that spacial mobility is synonymous to emancipation, mainly due to the physical distance with Rey-Bouba's lamido ${ }^{25}$. If these different collective identifications have sociocultural objectives (cultural promotion, economic development, demands for the reclassification of chiefdoms), the Mboum Cultural Dynamics (MCD) also contributes to the trivialization of public anger.

\subsubsection{The trivialization of public anger}

With democratization, the Mboum understood the importance of the trivialization of public anger as a modality of social renegotiations of the balance of power in the Touboro sub-vision. By politicizing public anger, the Mboum community is pushing its demands through public debates in order to generate general interest in their cause. Certainly, if we stick to their statutes and internal regulations, the Mboum Cultural Dynamics (MCD) is an apolitical association pursuing socio-cultural and economic objectives. However, in practice, the real stake of this association remains the political integration of the Mboum community. The cultural character masks the political objectives (Bigombe Logo, 1999, p: 250 cited by Assana, 2017). In the 1990s, we observed a relative but real break in the political economy of the loyalty and defection of the ethnic population of the slavish Mboum origin, when we remember the criminalization of politics and the violation of human rights in the Division of Rey-Bouba (Mouiche, 2005, p.12). The trivialization of public anger as a mode of political expression is the consequence of the crisis of authoritarianism and the politicization of public anger (Assana, 2014: p.223). Democratic culture appears as a culture of secularization of national and local leaders, notably the lamido of Rey through the popularization and trivialization of the culture of interposition. In the present case, democratic culture in material form is marked by the rediscovery of new ranges of political expression consisting, among other things, of memoranda, requests, and letters of interposition as supports for mobilization against the hegemony of the lamido of Rey-Bouba ${ }^{26}$. Within the framework of this study, we are interested in the various operations of construction of the activity of framing these unconventional political practices. In the democratic movement, the specific work of enunciating and publicly formulating the "mboum problem" evolves around the political, legal, and administrative dimensions:

On the political level, the stake of the "mboum problem" is constructed in the form of political marginalization; the sad observation of the almost total absence of Mboum sons and daughters from state structures where the fate of our country is at stake. According to the memorandum, this marginalization is out of the segment with the installation of the first Mboum in these regions (Assana, 2014).

The legal dimension of the construction of the "Mboum problem" constitutes another modality of social renegotiations of the liberation of the Mboum community from the tutelage of the Rey-Bouba lamidate in the context of liberalization and democratization. The memoranda, collectives, and joint declarations present the "mboum problem" in the form of physical and public violence to which the Mboum are subjected to. Primarily, the memoranda and petitions proceed from the scandalous construction of the "Mboum problem" through stigmatized categories such as cruelty, beatings and massive human rights violations. These are materialized through the denunciation of the various abuses which have multiplied to the Mboum community in the Rey Bouba division for several years already. The extent and systematization of human right violations exercised by the lamido of Rey-Bouba on the Mboum populations of the Touboro sub-division is manifested through what the Mboum describe as "slavery" and other particularly revolting inhuman practices. The abuses on the Mboum community have worsened since the events of March 28, 2011. The Oeil du sahel Newspaper echoed it in these terms:

The serial repression initiated by his majesty the lamido of Rey-Bouba, Aboubakary Abdoulaye against the Mboum seems only to begin. After having confiscated a few weeks ago the invitation letters of the village chiefs to the next congress of the Mboum Cultural Dynamics (MCD), we learned that the almighty Chief has moved to another speed. The Lamido after having confiscated the invitation letters, decided to keep 20 or more mboum Djaouro from his kingdom in his courtyard. They are thus 27 villages and cantons to be sequestrated behind the walls of the royal palace, with a ban en from going out, or even speaking to anyone since March 19, 2011. This confinement, we learn from a good source lasted until March 25, 2011. The djaouros were released only after having given up any idea of mobilizing their mboum brothers for the congress which ought to hold from August 7 to 9, 2011 (...). "The 1990 law on freedom of association can only be applied in Yaoundé, not here”, lamido said to the Djaouro confined to his palace. A statement which obviously refered to the association of Mboum natives, who intended to relaunch their Cultural activities after ten years of lethargy. According to corroborating sources, his majesty Aboubakary Abdoulaye would

${ }^{25}$ On migration as and emancipation, read Bidet, 2018: 125-147 cited by Olivier Laservoisier, 2020, p.33).

${ }^{26}$ On the mobilization of memoranda, letters of inquiry and requests from traditional Mboum chiefs, read Assana, 2017. 
suspect the Lamido Hayatou of Ngaoundéré of encouraging the regrouping of the Mboum, to better exercise control over a good part of the Division of Mayo-Rey (...) (Cf L'oil du Sahel N ${ }^{\circ} 423$ of March 28, 2011: 3 cited by Assana, 2014).

Danièle Lochak rightly points out that: We cannot, even in a democracy, rely solely on power or judges to guarantee freedom. Respect for human rights also depends on the ability of citizens to mobilize to defend them, to transform them into a civic "cause" (Danièle Lochak, 2005: p. 78). The Mboum believe they can protect themselves against human rights violations or acts of abuse of power by the Rey-Bouba lamido through the mobilization of memoranda, collectives and letters of inquiry. These memoranda open up the possibility of extending the scope of political action at the national or even international level. These are the methods of building public space in the Touboro sub-vision, where deliberations and decisions without disregarding the lamidal order tend to be taken on a broad basis (Habermas, 1997 cited by Assana, 2017). However, the pursuit of community goals does not exclude personal ambitions. Let us follow in this regard, an informant, former member of the Mboum Cultural Dynamics (MCD):

In the original philosophy, the Mboum Cultural Dynamics involved in promoting Mboum culture, the socioeconomic development of their community and the reconstruction of collective identity. There was no question of playing politics. Certainly, since Ganhoul Daniel (retired senior civil administrator) took control of the Mboum Cultural Dynamics, he has greatly transformed the association which is now at the forefront of the defense and promotion of the interests of the Mboum people in Cameroon. But he is inclined towards political conservatism, on the understanding that, since the creation of this association in 2004, he has monopolized the presidential chair. The challenge is to remain the privileged interlocutor between the Mboum community of Cameroon and the central power in order to return to the manger in a context where officials fear political and administrative retirement like a plague (Interview of 21 /01/2020 in Mbaiboum).

The monopolization of the presidential chair of this ethno-community association is seen by some members as a personal achievement to the detriment of community interest. It also reveals how associative movements can be the subject of a certain political instrumentalization.

\section{CONCLUSION}

The objective of this study was to study the issues of political participation on the dynamics of renegotiations of the emancipation of the group of the slavish Mboum origin from the tutelage of the Rey-Bouba lamidate in the democratic movement, based on the case of the Touboro sub-division in the North region of Cameroon. We can observe a favorable global evolution in the situation of the descendants of Mboum slaves, which can be explained by the democratization and its corollary multipartism, given that fact that, multipartism leads to the diversification of partisan offer in the democratic movement and it enshrines social mobility and the emancipatory trajectories of individuals which increases the uncertainties of the systematic link that could be made between social status and political success. The fact remains that this favorable situation for the reorganization of the balance of power does not enshrine the total liberation of the Mboum community from the tutelage of the Rey-Bouba lamidate. On close examination, the trajectory of the emancipation of the Mboum group of slavish origin from the supervision of the Rey-Bouba lamidate is complex and ambiguous. Social renegotiations have not yet been able to bridge the gap between the habit of subjugation to the Rey-Bouba lamidate, the desire for freedom and access to full citizenship. The historical burdens and the weight of habitus are rather slow to be erased in and on the conduct of the members of the Mboum community. Post-slavery period is an ambiguous period where the dividing line between past and present is difficult to draw in Touboro. Despite some legal and political progress, the mobilization capacities for the liberation and emancipation of the Mboum community are limited by the logic of ethnoclan and religious fragmentation on one hand, and the conservative capacity for adaptation of the Rey-Bouba lamidate on the other hand.

\section{ACKNOWLEDGMENT}

I express my gratitude to the Alexander Von Humboldt Foundation for offering me a 06-month internship in Germany which enabled me to write this article. I am also grateful to the Arnold Bergstraesser Institut (ABI) in Freiburg who served as my home laboratory. Finally, I am grateful to Mouiche Ibrahim, who has been a discussion partner and a keen reviewer. May they all find here an expression of my gratitude.

\section{RÉFÉRENCES}

Abe Claude, «Les systèmes politiques traditionnels centralisés du monde rural face à la multiplication de l'offre partisane et à la mutation du personnel politique local au Cameroun : l'expérience du lamidat de Rey Bouba (NordCameroun) », Les mondes ruraux à l'épreuve des sciences sociales, Dijon, 17-19, mai 2006, pp.202-217.

Ahmadou Sehou, «Esclavage, émancipation et citoyenneté dans les lamidats de l'Adamaoua (Nord-Cameroun) », Esclavages et Post-escalvages (en ligne), 1/2000, mis en ligne le 20 novembre 2019. Consulté le 04 janvier 2020. 
Alerte du $\mathrm{N}^{\circ} 034$ du 28 avril au 15 mai 2015.

Alerte $\mathrm{N}^{\circ} 039$ du 28 avril au 15 mai 2015.

Arcand, Sébastien, Les minorités ethniques et l'Etat québécois: participation et représentations sociales des associations de groupes ethniques minoritaires lors de commissions parlementaires, 1974-2000, Thèse de doctorat en sociologie, Département de sociologie, Université de Montréal, 2003.

Assana, « les memoranda, les motions de soutien et la consolidation de la démocratie participative au Cameroun », Revue Béninoise de Science Politique, volume 04, Numéro 01, pp. 198-256.

Assana, Assana, «Memoranda et démocratisation dans l'Adamaoua (Cameroun) : mutations des modes de participation politique ou entreprise d'instrumentalisation ", L'ordre public écologique. Du concept à la juridicité, Droit et culture, Revue internationale interdisciplinaire, 68, 2014, pp. 213-246.

Assana, Démocratisation, ethnicité et recherche hégémonique locale au Cameroun : le cas de la région de l'Adamaoua, Thèse rédigée et soutenue publiquement pour l'obtention du Doctorat/Ph.D. en Science Politique, Université de Yaoundé, septembre, 2017.

Bennafla Karine, « Maiboum : un marché au carrefour de frontières multiples », Autrepart, (6), 1998, pp.53-72.

Bernard Lahire, L'homme pluriel. Les ressorts de l'action, Nathan, Paris.

Bratton Michael, Van de Walle Nicholas, Democratic Experiments in Africa, Cambridge, Cambridge University Press, 1997.

Danièle Lochak, Les droits de l’homme, Paris, Edition la Découverte, 2005, 78.

Deoyo Paul, «The Concept of Mang-djala reference to church unity in all context of ethnic diversity : The case of evangelical Lutherian Church in Cameroon (EELC) », Doctor of philosophy in religious studies, University of Kwazulu-Natet, 2013.

Easton, L'analyse du système politique, Paris, Armand Colin, 1974.

Fogui Jean-Pierre L'intégration politique au Cameroun. Une analyse centre-périphérie, Paris, LGDJ, 1990.

Gerber Linda M., "The Visible Minority, Immigrant, and Bilingual Composition of Ridings and Party support in the Canadian Federal Election of 2004", Canadian Ethnic Studies, 38, 1, Ethnic New Watch (ENW), 2006, pp.6582.

Grosfoguel Ramón, “ Race and ethnicity or racialized ethnicities. Identity within global coloniality”, Ethnicitie, 4 (3), 2004, pp.315-306.

Joya Jean, « Démocratisation et légitimité traditionnelle en pays bamoun : de la personnalisation de l'expression politique à la subversion sociale », Revue Polis, vol.1, numéro spécial, février 1996, pp.1-11.

Kuate Jean-Pierre, Les élections au Cameroun. L'élection des conseillers municipaux et du maire, MACADOS, Douala, 2002

L'article 22 du décret N²013/332 du 13 septembre 2013 modifiant et complétant certaines dispositions du décret $\mathrm{n}^{\circ} 77 / 245 \mathrm{du} 15$ juillet 1977, portant l'organisation des chefferies traditionnelles.

L'œil du Sahel N443 du 16 août 2011.

La Réplique relative à la plainte contre sa Majesté le Belaka Mboum-pana (2eme module par R.B).

Lacroix, Notes sommaires sur la subdivision de Rey Bouba, Yaounde, Archives nationales, 1950, $23-5$. 
Laservoisier Olivier «La migration comme émancipation? Pluralité des classements sociaux et recompositions des rapports de pouvoir au sein de la société Haalpulaar (Mauritanie-Sénégal) », Politique africaine, $\mathrm{n}^{\circ} 159$, 2020/3, pp.33-50.

Laservoisier Olivier, «Démocratisation et renégociations sociales : les enjeux de la participation politique des groupes d'origine servile haalpulaaren en Mauritanie », Politique africaine, n¹1, juin 2009, pp.24-43.

Laservoisier Olivier, «Les héritages de l'esclavage dans la société haalpulaar de Mauritanie », Journal des africanistes, 78-1/2, 2008, pp.247-267.

Lochak Danièle, Les droits de l'homme, Paris, Edition la Découverte, 2005

Miaffo Dieudonné, Chefferie traditionnelle et démocratie : réflexion sur le destin du Chef en régime pluraliste, Douala, CEDILA, 1993.

Motaze Akam André, Le social et le développement en Afrique, Paris, L’Harmattan, 2009.

Mouiche Ibrahim « Autorités traditionnelles, multipartisme et gouvernance démocratique au Cameroun », Afrique et Développement, vol.XXX, n4, 2005, pp.221-249.

Mouiche Ibrahim Démocratisation et intégration sociopolitique des minorités ethniques au Cameroun. Entre dogmatisme du principe majoritaire et centralité des partis politiques, Dakar, CODESRIA, 2012.

Mouiche Ibrahim, «Autorités traditionnelles, multipartisme et gouvernance démocratique au Cameroun », Afrique et développement, Vol.XXXn N4, 2005, pp. 221-249.

Mouiche Ibrahim, «Multipartisme et participation politique des chefs traditionnels au Cameroun de l'Ouest », Revue Africaine d'Etudes Politiques et Stratégiques n 1, 2001, pp. 55-81.

Mouiche Ibrahim, «Ethnicité et multipartisme au Nord-Cameroun », African Journal of Political Science, 5 (1), 2001, pp.46-91.

Mouiche Ibrahim, «Processus électoraux et rotation locale des élites Cameroun », in Law and Politics in Africa, Asia and Latin America $\mathrm{n}^{\circ}$ 4, 2004, pp.401-432.

Mouiche Ibrahim, Les minorités ethniques et les défis de la représentation politique au Cameroun (version provisoire), 2011.

Niang Abdoulaye, La jeunesse et le changement social, in Assogba Yao (Dir), La jeunesse en Afrique subsaharienne, Laval, Pul, 2007.

Norbert Elias, Qu'est-ce que la sociologie ? Paris, Editions de l'aube, 1991.

Nyamjoh Francis et Rowlands, Michael, 'Élites Associations and the Politics of Belonging in Cameroon' in Africa, vol 68, n³, 1998, pp.320-337.

Olivier Nay (dir.), Lexique de science politique. Vie et institutions politiques, $2^{\mathrm{e}}$ édition, Paris, Dalloz, 2011.

Oomen Barbara, Chiefs! Law, power and culture in Contemporary South Africa, University of Leiden, 2002.

Ouedrago Jean Baptiste, "The articulation of the Moose Traditional Chieftaincies, the Modern Political System and the Economical Development of Kaya Region, Burkina Faso’in Journal of Legal Pluralism n³7/38, 1996, pp.249-261.

Passeron Jean-Claude, Le raisonnement sociologique. L'espace non-poppérien du raisonnement naturel, Paris, Nathan, 1991.

Perrot Claude-Helene et Fauvelle-Aymar, Francois-Xavier, Le retour des rois : les autorites traditionnelles et l'Etat en Afrique contemporaine, Paris, Karthala, 2003. 
Perrot-Clause Helene, Fauvelle Aymar François-Xavier, Les autorités traditionnelles et l'Etat en Afrique contemporaine, Paris, Karthala, 2003.

Plan Communal de Touboro, 2014.

Rapport Mondial sur le Développement Humain, 2004.

Rocher Guy, Introduction à la sociologie générale : action sociale, organisation sociale, changement social, Canada, Hurtubise HMH-Ltee, 1992.

Schmitz Jean , «L'élection divise. La politique au village dans la vallée du Sénégal», Afrique contemporaine, $\mathrm{n}^{\circ}$ 194, 2000, pp.34-46.

Seignobos Christian, «Une négociation foncière introuvable? L'exemple du Mayo-Rey dans le NordCameroun », Colloque international ' Les frontières de la question foncière-At the frontier of land issues, 2006, pp.1-21.

Sindjoun Luc (dir), « Le paradigme de la compétition électorale dans la vie politique : entre tradition de monopole politique, État parlementaire et État seigneurial », la révolution passive au Cameroun, Dakar, Codesria, 1999, pp.269-325.

Sindjoun Luc, L'État ailleurs. Entre noyau dur et case vide, Paris, Economica, 2002.

Taguem Fah Gilbert L., Les élites musulmanes et la politique au Cameroun de la période française jours, Thèse de doctorat 3eme cycle, Université de Yaoundé I, 1996. 